\title{
Shaping Social and Psychological Competencies or Intervening in a Crisis? Sociotherapists' Experiences of Helping Adolescents in Poland
}

\author{
Emilia Soroko ${ }^{1}$ (D) $\cdot$ Barbara Jankowiak ${ }^{2}$
}

Published online: 12 June 2020

(C) The Author(s) 2020

\begin{abstract}
Sociotherapists' experiences of helping adolescents within the framework of sociotherapy were examined. There were 12 participants involved (three males), who were active sociotherapists from big cities in Poland. They were aged 30-60 years, with at least 4 years' experience in the profession. We applied a qualitative approach to obtain indepth, socio-contextual descriptions of the sociotherapists' experiences. Interviews activated by a narrative stimulus were conducted. Both inductive (inspired by thematic analysis and a categorical-content perspective in narrative analysis) and deductive (based on theory of basic narrative forms) content analytic approaches were used to identify key helping factors. Two general themes revealed different paths of arranging help for adolescents in sociotherapeutic groups: (1) shaping of psychological competencies; (2) intervening in crises, encompassing dramatic actions going beyond process-based group work. Sociotherapy providers should have appropriate specialisms and procedures to implement the necessary interventions, as they go beyond the scope of the group-work aspect of sociotherapy.
\end{abstract}

Keywords Sociotherapy · Group work · Adolescence · Qualitative analysis · Poland

\section{Introduction}

Young people entering adolescence experience many dynamic developmental changes that influence their psychological health (Sales and Irwin 2013). The importance of research on

Emilia Soroko

soroko@amu.edu.pl

1 Qualitative and Mixed-Methods in Clinical Psychology Research Lab, Department of Health Psychology and Clinical Psychology, Faculty of Psychology and Cognitive Science, Adam Mickiewicz University, Poznań, Poland

2 Unit for Psychopedagogical Research on Human Development, Faculty of Educational Studies, Adam Mickiewicz University, Poznań, Poland 
adolescence is well-recognised, viewing it as a period of rapid growth, learning, adaptation, and formational neurobiological development in which young lives can pivot rapidly in both negative and positive directions (Dahl et al. 2018). Despite the fact that most young people successfully cope with the physical, cognitive, and emotional challenges, adolescence is perceived of as an important time for: (1) optimizing development for those who have developed competent ways of coping; and (2) therapeutic activities for those who have experienced psychological problems and/or psychopathology, associated with experiences such as drug use/abuse, violence, and school-related behavior problems that are widespread among adolescents of all cultures, ethnicities, and communities (Sexton et al. 2015). In the case of those in the latter group, adolescence is an important window for supporting change in order to restore a more appropriate developmental trajectory, especially in those adolescents at risk of school disengagement, severe social dysfunction, or mental health problems (Cicchetti and Rogosch 2002; Dryfoos 1990; Sexton et al. 2005). Thus, developmental potential and the possibility of developmental disruption interact dynamically, and adolescence undoubtedly provides an important opportunity for both preventive and therapeutic activities (Holmbeck et al. 2000; Takanishi 1993; Weisz 1997).

Effective helping interventions toward adolescents, however, are still an area requiring the mutual enrichment of science and practice. On the one hand, the evidence-based prevention and treatment trend is developing dynamically and obliges professionals to seek out the most effective interventions for individuals and groups, contributing to a higher standard of professional practice (Das et al. 2016; Kazak et al. 2010; Kieling et al. 2011; Silverman and Hinshaw 2008). On the other hand, real-life practice, with all its shortcomings (especially treating groups with very diverse problems), needs to be examined in terms of its effectiveness and value. Either way, the focus should be directed to the psychological and interpersonal processes activated in the course of providing professional help that may contribute to clarification and diversification of this help.

Sociotherapy is a method of helping young people who are situated between mental health and psychopathology (Jankowiak and Soroko 2020). It emphasizes socioenvironmental and interpersonal dynamics rather than intrapsychic factors. The approach largely involves a combination of psychological and pedagogical/educational approaches for helping interventions, and is relevant to the social, cultural, and economic background of people in Poland.

In this study, we sought to examine the experiences of sociotherapists concerning helping activities directed toward adolescents within the framework of sociotherapy. Since scientific research on sociotherapy is just beginning, we will first characterize this set of likely interventions and then present exploratory research conducted with a qualitative approach, bringing a better understanding of the help that sociotherapists typically offer.

\section{Sociotherapy in Poland}

Sociotherapy is one of the most common forms of help for young people in Poland. It is a group psychological and pedagogical method used in working with children and adolescents at risk of developing mental and behavioral disorders, or those who already manifest problems in psychosocial functioning (Grudziewska 2015; Jankowiak and Soroko 2013; Sawicka 1999; Szczepanik and Jaros 2016; Wilk 2014). The work of sociotherapists typically occurs within school settings or in specialist facilities. Sociotherapy aspires to be a form of professional help, through being a targeted activity starting with assessment through to intervention and then to evaluation of the intervention. It is based on intentional triggering (activating) of helping 
factors using group processes and the relationship with the sociotherapist (e.g., group cohesion, identification with the adult, feedback from peers) in order to: (1) activate developmental potential (social, emotional-motivational, cognitive); (2) prevent the development of health disorders and problems; and (3) change nonadaptive behaviors, emotions, and beliefs. Depending on the conditions of the sociotherapy involvement (e.g., setting, group composition, competence of the sociotherapist, or seriousness of the participants' difficulties), a given group of young people may engage more in psycho-educational interactions and another with more therapeutic goals (Jankowiak and Soroko 2020).

Sociotherapy as a psychological and pedagogical service for adolescents is offered in Poland universally. It is conducted both in so-called sociotherapeutic day-rooms (especially dedicated to sociotherapy, but where sometimes more general social assistance is also provided), family support centers, health centers, and other facilities in the private and public sectors. It is quite well accepted and is typically perceived of as being relevant by teens, parents, and teachers. It takes place typically involving a group of peers, integrates well into extracurricular activities, and often becomes a significant point of reference for the participants. Sociotherapy is largely treated as a form of help operating somewhere along a continuum involving psychotherapy, psycho-education and interpersonal training (Sawicka 1999). Most often a meeting begins with work in a circle, followed by interactive exercises, discussed from psychological and psycho-educational points of view. Closed short-term groups are advocated.

Sociotherapy is often used in response to initial signs of problems in psychosocial functioning that are noticed by those within the educational environment (e.g., class teacher, school staff, parents) or within other contexts following a perception that the child in question comes from an environment where there are difficulties. It is aimed at youth who manifest various problems, from externalization (e.g., aggressive behavior or the use of psychoactive substances) to internalization (e.g., shyness, fear, low self-esteem), or/and those who do not have social resources (e.g., lack/excess of control or bonds in the family home or lack of acceptance by peers). In this sense, therefore, both health and disability models are drawn on for describing, explaining and addressing the functioning of those in need (Jankowiak and Soroko 2020).

Sociotherapeutic interventions might be deemed: (a) universal — primary prevention, health promotion, facilitation of development of healthy young people; (b) selective - secondary prevention for high-risk groups of individuals; or (c) indicated - tertiary prevention, designed to minimize the negative impact of maltreatment and prevent the recurrence of further problems (Crockett and Petersen 1993; Gonzalez and MacMillan 2008; Gullotta 2015). Importantly, these different types of interventions can occur simultaneously if one considers not only the target population but also the targeted problems. For example, in a group of adolescents, in the case of some problems (e.g., risky sexual behavior), some will need secondary prevention and some primary prevention.

Despite the established practice, and because of the great diversity of this form of assistance, scientific reflection on sociotherapy is at an early stage, both in terms of research on sociotherapy or sociotherapists and the development of theoretical approaches. For this reason, conducting research in this area is essential for the professionalization of this form of assistance in Poland and may contribute to enhance its effectiveness.

The problem focused on in this study concerns the process of helping in sociotherapy, which covers a number of intentional interventions. We assume that sociotherapists mobilize (activate) helping factors in response to the perceived problems of participants and groups as a whole using their professional preparation and understanding of the current individual and group issues (Jankowiak and Soroko 2013). Although group work with adolescents has been a 
focus of research, none, to date, has focused closely on the sociotherapists' experience of actual helping factors and how those factors are related to the discerned outcome of the helping process.

\section{Research Questions}

This study sought to explore sociotherapists' experiences of group work with adolescents in school and non-school settings in Poland. It focused on key helping factors in sociotherapy and their consequences (the experienced effects of interventions: progression, regression, no change). Particular questions were: (1) what key helping factors can be identified through self-narratives about the experiences of group work with adolescents in both school and nonschool settings?, and (2) what themes can be identified in terms of the dynamics of such helping over time (progressive, regressive, stable)? A qualitative approach was undertaken to answer those questions, as it was seen as desirable to obtain in-depth and rich data, more than a superficial and quantified perspective.

\section{Method}

\section{Study Design}

The study presented here was part of a larger project aimed at examining sociotherapists' and teachers' perceptions of adolescents in Poland (Jankowiak 2017). Here, we focus on sociotherapists' experiences of acting in the arena of group work with adolescents in order to identify key helping factors. We adopted a constructivist approach (Savin-Baden and Howell Major 2013). Personal practical knowledge develops when actions are both the expression and origin of the personal knowledge of the actor (Clandinin 1985; Goddard and Foster 2001).

Choosing between a declaration-based approach (asking directly about helping factors that are intended by a sociotherapist and which are components of his/her professional repertoire) and a recounted action-based approach (where identifying helping factors is addressed indirectly by medium of a story about those being helped) we decided for the latter. From this view, it is recognized that helping factors are inherently present in group work, and by asking participants to tell a story about a significant event portraying adolescent functioning, we aimed at identifying a reconstruction of the helping elements (according to the landscape of action and consciousness, Bruner 1986).

Thus the sociotherapists were asked to tell a story about their own group work experiences focused on their perception of adolescents' functioning to convey conscious and unconscious beliefs and reflections that had arisen for them from this experience. Based on a narrative mode, we were able to seek out what problems of functioning were encountered and what actions were taken - why, when, by who and with what result? Thus, we identified actions that indicated non-declarative helping factors from expressed actions that had been recognized as being helpful. Moreover, we hope that we have been able to contextualize the actions in everyday terms, diminish personal impressions, and gain access to something recognized as procedural (not solely declarative) knowledge. From a broad perspective, we aimed at transferring these less controlled expressions into conscious knowledge and to better understand sociotherapy as a form of help offered to adolescents. 
In keeping with the assumptions outlined above, we used a qualitative approach in order to obtain in-depth, socio-contextual and detailed descriptions and interpretations of the research topic (see, for example, Vaismoradi et al. 2013). This resulted in: (1) obtaining the sociotherapists' perspectives on their professional experiences of group work with adolescents; (2) using qualitative methods for collecting data; namely, interviews activated with a narrative stimulus (Soroko 2009); and (3) applying qualitative analysis influenced by thematic content and narrative analyses (Braun and Clarke 2006; Hiles and Cermák 2008; Hsieh and Shannon 2005; Mayring 2000; Saldana 2009).

\section{Participants}

Participants were 12 active sociotherapists from big cities in western Poland (see Table 1). They worked with adolescents in institutions such as schools and in non-school settings (psychological and pedagogical counselling centers, family support centers, psychological and pedagogical centers, and therapeutic outpatient clinics). Participants were aged between 30 and 60 years, with at least 4 years' experience as a sociotherapist (maximum 30 years). They led between one and ten groups a week, with 5 to 15 adolescents in each group. All were educated to a high level with a documented post-graduate specialty in sociotherapy.

The research adhered to guidelines for the protection of human subjects (APA 2017). Participants gave informed consent that encompassed: (1) participating in the interview and telling their personal story about their group work with adolescents; (2) audio-recording and transcription of interviews; and (3) citing fragments of interviews for publication purposes after anonymizing procedures.

We used purposive sampling with a snowball technique (Patton 2002). Participants were found by drawing on the professional networks of members of the research team and they were personally invited to participate. We intended to achieve diverse perspectives, so we sought to include both sexes, different work experiences, and different geographical locations. At the same time, we homogenized the participant group according to the following criteria: based in big Polish cities (the countryside has different availability of psychological and pedagogical

Table 1 Basic information about participants

\begin{tabular}{|c|c|c|c|c|c|c|c|}
\hline $\begin{array}{l}\text { Name } \\
\text { (Psuedonym) }\end{array}$ & Age & $\begin{array}{l}\text { Professional } \\
\text { experience } \\
\text { (years) }\end{array}$ & $\begin{array}{l}\text { Primary } \\
\text { education field }\end{array}$ & Type of centre & $\begin{array}{l}\text { Age (of } \\
\text { members) }\end{array}$ & $\begin{array}{l}\text { Number of } \\
\text { groups per } \\
\text { week }\end{array}$ & $\begin{array}{l}\text { Avge size } \\
\text { of groups }\end{array}$ \\
\hline SAMANTA & 30 & 4 & Psycholgy & Facility & $6-18$ & 10 & 7 \\
\hline SŁAWOMIR & 31 & 4 & Psycholgy & Facility & $6-20$ & 10 & 8 \\
\hline SARA & 32 & 8 & Pedagogy & Facility & $13-15$ & 4 & 7 \\
\hline SYLWIA & 36 & 8 & Pedagogy & Facility & $13-15$ & 2 & 8 \\
\hline SYLWESTER & 42 & 18 & $\begin{array}{l}\text { Pedagogy, } \\
\text { Polish filology }\end{array}$ & Facility & $13-18$ & 3 & 7 \\
\hline SELMA & 41 & 17 & Pedagogy & Facility & $13-19$ & 2 & 8 \\
\hline SANDRA & 33 & 10 & $\begin{array}{l}\text { Social rehabilitation } \\
\text { with social } \\
\text { prophylaxis }\end{array}$ & School & $13-15$ & 2 & 10 \\
\hline SŁAWA & 56 & 30 & Pedagogy & School & $14-17$ & 1 & 12 \\
\hline STEFAN & 57 & 27 & Pedagogy & Facility & $13-16$ & 6 & 8 \\
\hline SONIA & 37 & 13 & Pedagogy & School & $13-15$ & 2 & 15 \\
\hline SELENA & 51 & 25 & Pedagogy & School & $13-16$ & 3 & 10 \\
\hline STANISŁAWA & 60 & 20 & Pedagogy & School & $13-16$ & 2 & 7 \\
\hline
\end{tabular}


help) and working with adolescents at risk, but not from groups that were being psychologically treated for existing and socially difficult disorders in psychiatric hospitals or that were being re-socialized or rehabilitated in correction facilities. Thus, the collected data were specific to the sociotherapists' experiences of working with groups of adolescents centred on process-based group work (Yalom and Leszcz 2005).

\section{Researchers}

The research team comprised the two authors - ES (psychologist) and BJ (psychologist/ educationalist). Both are engaged in the professionalization of sociotherapy in Poland and our collaboration of many years' standing was formally grounded in a Faculty Research Group on Psychological and Pedagogical Aspects of Sociotherapy. Interviews were conducted by BJ, who is experienced in group work with adolescents at risk. Qualitative analysis was designed by ES and undertaken (with the use of Atlas.ti 6.2 software) by both researchers.

Our clinical experience as psychodynamic psychotherapists (familiar with psychopathology, clinical psychology, and psychotherapy) might have influenced the generation of themes by us being particularly sensitive to implicit meaning, but our academic experience contributed to the regularity, meticulousness, and recursiveness of analysis. Twice in the study we relied on the help of two independent coders from a research team who had previous experience in the analysis of narratives and were properly trained in that regard.

\section{Data Collection}

One of us (BJ) conducted in-depth, semi-structured interviews focused on the sociotherapists' perceptions of adolescents they were involved with. For the purposes of the portion of the present study (in the context of the larger study), each interview commenced with a narrative stimulus that elicited a story about the participants' experiences of group work with adolescents ("You work professionally with young people. I have also worked with adolescents for many years and I know that there are stories that we remember for a long time. Please tell a story about a significant event for you where you were involved in group work with adolescents that can illustrate how young people function today. What did you learn from this experience?").

The whole interview protocol was quite well defined and the aim of the whole research project was conveyed in the first instance. Before the storytelling commenced, the interviewer presented some expectations about the telling of the story and also indicated a sentence or gesture for the coda (the clause or clauses that bring the narrative back to the time of its telling; Labov 2009); and (2) indicated there would be no interference in the story following the initial narrative stimulus. The interviewer did not provide any comments until the coda was signaled by the participant, and then the research interview continued according to the protocol. As mentioned, there was no direct question as to what the sociotherapist had been doing to help adolescents, but the broad instruction allowed participants to tell their life-stimulated story in their own way.

We were aware that those participating in the study could experience the interviews in different ways (e.g., as an opportunity to express emotions related to difficulties at work, storytelling motivated by self-presentation and seeking support, or as a space to rationalize or reflect on the actions undertaken). Taking into account the experience of the interviewees, we found that participation itself was often a significant personal experience. One sociotherapist 
(Sławomir) said: "I am glad that we met each other, because at the moment of conversation it is so enriching for us, and when we talk, we also learn something about our work".

Except for in the city of Poznan, where the sociotherapists $(n=3)$ chose BJ's private office as a meeting place, the interviews were conducted in the institutions where the sociotherapists worked. Interviews lasted between 45 and $105 \mathrm{~min}$ (60 min on average). The interviews were recorded using a digital voice recorder and transcribed verbatim by a person from outside the research team, and then listened to and checked for accuracy by the interviewer (BJ). No transcription notations were used, but the recordings were listened to in case of doubt during and after the coding phase.

For the purpose of this analysis, the narrations obtained following the narrative stimulus were marked and evaluated by the two independent judges according to whether they met the criteria of self-narration - here technically understood as a continuous, uninterrupted autobiographical story concerning sociotherapy, in which one could distinguish the beginning, plot development, and coda (e.g., Labov 2009). Since some participants did not build-in selfnarration at the beginning of the story invitation, as they were asked to do, but then during the interview they remembered stories that they believed were good responses, the later storiesafter being identified and judged by the two experts as self-narrations - were included in the analysis. The final self-narrations were divided into verses, each of which was a distinct sentence (usually containing one verb). As a result, 16 self-narrations were analyzed, which had an average of 464.82 words (Median 335 [Q1=219; Q3 =470]; Min=150, Max=1868).

\section{Data Analysis}

In the study, both inductive and deductive content analysis approaches were used (Hsieh and Shannon 2005; Mayring 2000; Saldana 2010). The inductive approach was inspired by thematic analysis (Braun and Clarke 2006) and the categorical-content perspective in narrative analysis (Hiles and Cermák 2008), and served to identify key helping factors largely indirectly revealed in the stories told about the functioning of adolescents in the group environment. Deductive analysis was based on the theory of basic narrative forms (Gergen and Gergen 1997) and also addressed the representation of perceived outcomes of the helping process.

\section{Key Helping Factors}

The main principles of thematic analysis were used to analyze the self-narrations in order to identify the key helping factors. The analytic procedure was carried out in parallel by the two researchers (authors of the paper). We did some of the work independently, while some was discussed in order to obtain better coding accuracy and repeatability of the analysis. We separately started the analysis by listening to the interview, then reading the whole transcript, and then re-reading the self-narration after being distinguished and transcribed in the form of verses. This procedure made it possible to embed further detailed analytical work in the context of the whole interview and to stay close to the data through immersion (Vaismoradi et al. 2013), especially by facilitating concentration through getting more closely acquainted with the interviewees' ways of speaking.

In each self-narration, we independently identified key quotations that best illustrated the sense of the sociotherapist's activity in regard to the participants, and then labeled these quotations (in various expressive terms). We pushed ourselves to make a choice about what fragment in the story could be considered the most significant (outstanding and crucial) for the 
help presented to the adolescents. We did that because we aimed not to analyze every manifestation of the sociotherapists' activities in general but sought, rather, to discover the essence of what they were trying to convey about their experiences in their stories. Thus, the narrative elements (a pause or an emphasis, for example) guided us in capturing the individuals' meanings within the self-narrations (Ayres et al. 2003). After this individual phase, we conferred on quotations and labels, explaining the choices and discussing until agreement was reached on the list of key quotations and their labels. We observed that labels did not repeat across the cases - that is, they were unique to each self-narration.

Each of us then independently developed themes (common threads linking the labeled quotations), and a joint meeting was subsequently held to discuss the results, cross-checking the process and comparing across cases to identify commonalities (Ayres et al. 2003). Then the list of themes was iteratively referenced by the first author to: (1) labels, checking whether each theme fitted the label and the quotation; and then to, (2) the self-narration, checking whether the theme reflected well the sense of self-narration; and, finally to, (3) the entire interview, checking to make sure that the theme was not contradictory to the message of the entire material. At this stage, any necessary corrections were made in the list of themes and the final result of the inductive analysis (the thematic framework) was iteratively referred to previously evaluated texts in order to check whether the themes were sufficiently complete and reproducible.

The result was a list of themes, labels, and quotations that was not a frequency list but a list of significant meanings about helping adolescents in sociotherapy (see Table 2). Then we engaged in discussion to explore various interpretations of the findings and to give evidence of confirmability of their theme location (see Vaismoradi et al. 2013). Through reading and rereading transcripts, as well as self-correcting processes, we reached an overall understanding of the data and distinguished the main issues in the phenomenon under study (see Morse 2008; Vaismoradi et al. 2013). Methods used for enhancing the quality of the coding process were investigator triangulation (independent coding), consensus on themes, analysis of all transcripts by the two investigators, and reporting on the reasons for theoretical, methodological, and analytical choices throughout the entire study (Nowell et al. 2017).

\section{Types of Self-Narration}

The deductive approach (based on the theoretical typology of narrations) served to classify the narratives as being progressive, regressive, or stable (see Gergen and Gergen 1997). This typology allowed recognition of the development of a plot over time, being the outcome of the helping processes conveyed. Deductive analysis of the content consisted of: (1) theory-driven definitions of the three main types of narration; (2) creating a manual for coding these three

Table 2 Procedure of analysis - key helping factor definition and basic rules of coding

\begin{tabular}{|c|c|}
\hline $\begin{array}{l}\text { Key helping factor } \\
\text { definition }\end{array}$ & $\begin{array}{l}\text { A basic sociotherapist's activity, which would lead to satisfactory help, showing what } \\
\text { the adolescent needs in order to make his/her work more optimal; this is a key sense } \\
\text { of the help that emerged from a story while reading it. }\end{array}$ \\
\hline Unit of analysis & $\begin{array}{l}\text { A quote (or quotation) from a self-narration that best illustrates the meaning of the } \\
\text { sociotherapist's activity. }\end{array}$ \\
\hline Unit of context & Whole self-narration in the wide context of the interview. \\
\hline Procedure & $\begin{array}{l}\text { 1. Indicate a fragment of the statement, that is the clue of a story told (mark } \\
\text { quotations). } \\
\text { 2. Give the quotation a name (label). }\end{array}$ \\
\hline
\end{tabular}


types of narrative, together with examples and the training of coders; (3) coding performed by the two independent coders (external researchers from the faculty, not involved in the study); (4) calculating the inter-rater agreement; and (5) establishing a typology for each narrative (see Table 3).

The coders completely agreed in all but one case (which was subsequently unequivocally resolved in the course of the discussion): therefore, no additional computations of inter-rater agreement were made. The types of narration were used to arrange all the analyzed themes into three groups, that represented the possible outcomes: a leading to success group (eight instances), a leading to failure group (four instances), and a leading to an unchanged (stable) condition (four instances).

\section{Findings}

The sociotherapists delivered self-narrations that enabled us to identify two main themes that were experienced as factors that were (or should be) activated in group work with adolescents. These two main themes were (1) developing relational and personal competencies; and (2)

Table 3 Themes and sub-themes of the key helping factors

\begin{tabular}{|c|c|c|}
\hline Theme & Sub-theme & Examples \\
\hline \multirow[t]{6}{*}{$\begin{array}{l}\text { Shaping relational and } \\
\text { personal competencies }\end{array}$} & $\begin{array}{l}\text { (a) Group work and } \\
\text { socialisation }\end{array}$ & $\begin{array}{l}\text { Availability of sociotherapeutic process (Sandra) } \\
\text { Learning skills adjusted to the age of group } \\
\text { participants (Sandra) } \\
\text { Consistency in group's participation (setting, group } \\
\text { cohesion) (Samanta) } \\
\text { Cooperation with parents (Samanta) } \\
\text { Accepting forum to exchange emotional content and } \\
\text { getting feedback from peers (Sylwester) } \\
\text { Socialisation (Selma) }\end{array}$ \\
\hline & $\begin{array}{l}\text { (b) Developing specific } \\
\text { competencies }\end{array}$ & $\begin{array}{l}\text { Perceiving the problem's bright side (Sylwester) } \\
\text { Drumming up self-reliance (Selma) } \\
\text { Activating developmental potential (Sławomir) }\end{array}$ \\
\hline & \multirow{2}{*}{$\begin{array}{l}\text { (c) Offering a relationship } \\
\text { with an adult professional }\end{array}$} & Development of closeness (Stanisława) (Sara) \\
\hline & & $\begin{array}{l}\text { Emotional learning in the relationship with involved } \\
\text { professional (Sara) } \\
\text { Presence of a stable relationship with a professional } \\
\text { (Sylwia) }\end{array}$ \\
\hline & \multirow[t]{2}{*}{ (d) Looking for deep reasons } & $\begin{array}{l}\text { Working with symptoms but trying to reach deeper } \\
\text { (Sylwia) }\end{array}$ \\
\hline & & $\begin{array}{l}\text { Becoming aware of child's problems (needs, } \\
\text { emotions, circumstances) (Sonia) }\end{array}$ \\
\hline \multirow[t]{5}{*}{ 2. Intervention in crisis } & $\begin{array}{l}\text { (a) Providing an adolescent } \\
\text { with counselling in crisis }\end{array}$ & $\begin{array}{l}\text { Confronting an adolescent during a conversation } \\
\text { (Sława) (Stefan) } \\
\text { Offering solutions to specific problems (Stanisława) }\end{array}$ \\
\hline & $\begin{array}{l}\text { (b) Rendering aid to } \\
\text { adolescent's family }\end{array}$ & $\begin{array}{l}\text { Serving as a mentor for the family members (Sława) } \\
\text { Replacing aspects of ineffectual parents in their } \\
\text { childcare function (Sława) (Sława) }\end{array}$ \\
\hline & \multirow{2}{*}{$\begin{array}{l}\text { (c) Protecting an adolescent } \\
\text { from abuse and neglect }\end{array}$} & Protecting a child (Sława) \\
\hline & & $\begin{array}{l}\text { Making difficult decisions about life (Sława) } \\
\text { intending to prove perpetrator's guilt (Selena) }\end{array}$ \\
\hline & $\begin{array}{l}\text { (d) Other forms of } \\
\text { intervention in crisis }\end{array}$ & Boundless commitment (Selena) \\
\hline
\end{tabular}


intervening in a crisis (see Table 3). In the report below we have linked the themes with information about the type of narrative involved and these in relation to the settings where the sociotherapy was conducted (schools or otherwise).

\section{Theme 1. Developing Relational and Personal Competencies}

The participants recounted making an effort to help adolescents to develop their relational (social) and personal competencies. This helping factor was situated within the group work, especially by the availability of the sociotherapeutic process during the different stages of adolescents' psycho-socio-sexual development; learning skills adjusted to the age of the individuals (Sandra); and enhancement of the process of socialization. For example, thanks to the work in a group, an adolescent is able to become more focused on his/her colleagues instead of him/herself or is able to listen without interrupting (Selma). Sociotherapy was seen as a unified activity targeted at delivering continuous relational experiences despite the difficulties or temporal absence; e.g., "This whole therapeutic process was also there, it started in primary school, and resulted in the development of these [improved] behaviors. It was as if these behaviors [problematic] had been extinguished in a significant way already in a gymnasium, and in the first grade of his lower secondary school he returned to this sociotherapy" (Sandra).

Consistency of group attendance was also highlighted, especially important for being able to handle the group setting, developing group cohesion, and often accomplished through the cooperation of the parents. This factor was described as something very important and promising, but at the same time almost impossible to acquire adequately in the groups conducted. Samata said: "They appear once, they do not appear once: there is a lack of consequence of the participation [...] they don't support themselves in the contract that they sign with us; neither children nor parents".

The group was also seen as an accepting forum within which to exchange emotional content and to get feedback from peers, not only about functioning in the group ("here and now") but also about life outside the group ("there and then"). It was well described by Sylwester: "This subject that came up about his father-somehow the topic emerged, he talked about it quite safely [...] My role is to bring about a situation where they share information with each other, so ... there's always an advantage to it".

The development of specific competencies was also an area of the sociotherapists' commitment. Among others, the most important of these were learning to look at a problem's bright side (as Sylwester said), and urging self-reliance, and receiving feedback even if it carries a risk of being disliked by the adolescent: "He was offended by me for another three meetings, because I ordered him to go by bus, but it really seems to me that this is an important element of his independence, taking responsibility" (Selma).

Some more general findings appeared in terms of activating the developmental potential of adolescents who had been seen as people without any vision or attention to their future, but were instead closed and passive. A sociotherapist whose narration was full of such notions (Sławomir) felt helpless and frustrated in working with groups, but at the same time he openly raised such issues as a personal reaction to adolescents and their problems.

The next important helping factor that emerged was a positive relationship with an adult professional, especially developing a sense of closeness - "close to my heart", "attachment" (Stanisława), "bond" (Sara) - which was perceived of as being a good basis for openness, emotional learning, and having the experience of an adult who is able to understand difficult 
emotions. Moreover, it was described as being very engaging for both sides, as in Sara's narration: "She was simply saying certain things, not beating about the bush. And then I got angry with her, of course. Of course, I talked about this anger, and she learned that in such a relationship - an adult with a teenager - there can also be a place for [expressing] anger".

The presence of a stable relationship with a professional ("I am the first therapist with whom she stays in contact" - Sylwia) was also indicated as being a helping factor per se, especially when adolescents are perceived of as having problems in being able to depend on a helping relationship and experience consistency in receiving psychological help.

The sociotherapists also worked with the use of their own cognitive capacities, looking for deeper reasons when striving to get in touch with the adolescents' problems. There were two aspects of this factor: (1) working with symptoms but trying to reach deeper (Sylwia), and (2) becoming aware of the individual's problems (needs, emotions, complex life circumstances) (Sonia). We found instances where such aims were satisfactorily completed - e.g., "I started to investigate [...] I have learnt to manoeuvre between the needs of a child [molested by her father] and legal issues [her father was a high-profile policeman]" (Sonia) - and where it is constantly in progress as an unresolved or unresolvable problem, as expressed by Sylwia: "I am always looking for a hint [...] of what is 'here and now'; I need to know all the time what this is all about."

To sum up, the theme 'developing relational and personal competencies' encompassed mostly those helping factors that may be embodied in process-based group work. We found here factors that are seen as very hard to acquire (e.g., group cohesion, deep understanding), but also that are seen as very common and achievable, not least by the fact of consistent attendance at a group (e.g., social learning, closeness). Moreover, this theme was expressed in both progressive and stable narratives, which implies that it was perceived as a way to success, or to maintain continuous work with no spectacular effects but also without a decline.

Shaping competencies was thus seen as a long-term, gradual process where (1) the group is involved as a community and seen as an opportunity to practice skills; and (2) the sociotherapist is involved in seeking solutions and serving as a reference point for group members.

When we compared the occurrences of the theme "development of competencies" with the context of sociotherapists' work (whether it was a school or not), we noticed that the development of competencies takes place mostly in groups run in institutions specially designed for sociotherapy. Only two aspects of shaping skills - becoming aware of participants' problems and age adjustment of the skills concerned-were also present when the sociotherapists worked in schools. This observation directed our attention to the fact that schools may not be a place where a socio therapist can build and shape the competencies of adolescents. We will also address this topic in the discussion section.

\section{Theme 2. Intervention in Crisis}

The second main theme was labeled 'intervention in crisis' because it encompasses an array of actions that are aimed at direct and quick help when an adolescent is perceived of as being in a very difficult psycho-social situation. We found this theme quite surprising, because it indicated that immediate help for severe problems is very wide-ranging (we identified many forms of intervention in crisis) and such ways of helping were narrated as promising solutions. Furthermore, such interventions were delivered mostly through individual contact (demanding a one-to-one relationship instead of within the group process); however, the pressing needs of 
the adolescents were recognized thanks to their attendance at a sociotherapeutic group and perhaps would have never been noticed elsewhere.

The first sub-theme in this overall theme was providing an adolescent with counselling in crisis. Counselling in crisis was delivered especially by confronting problems of an adolescent during an honest conversation. For example, one sociotherapist organized a meeting first with friends of an adolescent who was a victim of violence at home, and then with the victim herself (Sława). In a further example, an adolescent who escaped death after overdosing on narcotics had been boasting to his friends on Facebook about a narcotic trip. It was challenging for the sociotherapist during a difficult conversation in the hospital to give a less enthusiastic name to the adolescent's physiological condition: "I was mean: I told him that he was not on a high, he [had] just collapsed" (Stefan).

Providing an adolescent with counselling in crisis was also realized by offering solutions to specific problems and advising, as depicted in Stanislawa's self-narration: "She came with all the problems - somewhere along the way, there was a fire in her house or flat, it burned down completely. And I helped her; and then in such situations I supported her, told her what she could do, how to solve all kinds of issues and conflicts not only with peers, but also with her parents".

The second sub-theme in the area of helping in crisis encompasses rendering aid to the adolescent's family. Sociotherapists often served as mentors for family members (e.g., by advising, organizing educational meetings), even when such help might be rejected at the beginning of the sociotherapeutic process. As Sława said, even "the Senator came and asked how to deal with his child". Help aimed at the family also at times involved substituting for an ineffectual parent in their childcare function. The sociotherapist may perceive him/herself as the only adult able to assist an adolescent in hospital or to bring him or her back from the hospital and drive home safely. Where a parent has renounced care for their own child, a sociotherapist is sometimes required (even perhaps compelled) to fill the void:

I was going to the hospital with him, and of course I was assisted by the police because of his aggression, the ambulance [people] didn't want to take him. [...] The doctor was very surprised, because she called his mother, because I could not take the child out of the hospital. His parent has to take him away. And his Mom said she had full confidence in me: 'Please hand over all documents to the teacher and the teacher will take my son`. (Sława)

What is interesting, the mother called the sociotherapist a teacher, perhaps because sociotherapy was held in a school setting; however, it also indicates how undifferentiated was her child's social environment for her.

Protecting an adolescent from abuse and neglect was the third sub-theme of intervention in crisis. The sociotherapists confided that helping adolescents requires making difficult decisions about the fate of the individual in trouble (e.g., putting a child in a detoxification clinic), especially when neither parents nor institutions are delivering proper assistance. For example, Sława recounted: "I had written to the ombudsman for children's rights as follows: "who is going to take responsibility for his death?"' It seemed that an expressive and uncompromising attitude was the only chance to help the adolescent. Sociotherapists also indicated that they have to stand up for an adolescent when he or she is mistreated and nobody believes him or her. Sława said: "I wrote to the court that he cannot stay in the foster family [...] I was at the hearing [...] and I had a very good relationship with this boy: he told me everything".

A special instance of such protection was described by Selena, who intended to prove a father's guilt for sexually molesting his teenage daughter. She decided to assist the girl and her 
mother while visiting the gynecologist, and she tried to prevent them from changing their mind about revealing the offender: "We [mother, daughter and sociotherapist at the gynecologist's office] waited and I was afraid that they would run away, because that was what they wanted. I wanted to catch it [have it stated] in order to prove it. I knew I had to give proper evidence to convict someone and that he was guilty" (Selena).

In the domain of intervention in crisis, the boundless commitment of the sociotherapists was also noted. For example, Selena was intimidated (her car was demolished) by an unknown perpetrator after interceding for a teenage girl against her father. The girl had no support from the headmaster of the school where the sociotherapy was conducted, and she was sure that her commitment was something that eventually helped in this situation.

In terms of the type of narrative and the setting of the sociotherapeutic work, the theme of helping in crisis appeared almost exclusively in the stories of those sociotherapists who led groups in schools. Moreover, the narratives were told in a way that reflected a sense of either success or failure (progressive and regressive narratives were similar in number). Apart from Stefan's observation that confronting adolescents is a long-term job, with a kind of steady flow (stable narrative), all the other stories in school setting were characterized by a dramatic tale of adolescents and sociotherapists.

\section{Discussion}

Two general themes revealed different paths by which to arrange help for adolescents in sociotherapeutic groups. One was mostly based on rather slow and staged group work with a prolonged shaping of psychological (social, emotional) competencies. This factor turned out to be most important in non-school settings and was typically narrated in a progressive or stable way. Group work was crucial for shaping relational and psychological competencies, especially when the sociotherapist was focused on group processes rather than on individual participants (for similar results, see Kivlighan and Tarrant 2001). Helping adolescents is inevitably grounded in social relationships, both between the young people, between them and adults, and in relation to their own self (see, for example, Strzemieczny 1988).

These findings are related to the results of empirical studies that have been conducted to date about therapeutic factors in group work for adolescents (Shechtman and Gluk 2005; Yalom and Leszcz 2005). Results consistently show that group cohesiveness, catharsis, and interpersonal learning are the most important factors (Dierick and Lietaer 2008; Shechtman et al. 1997). Similarly, in our study, group cohesiveness was presented as problematic but a desirable condition for successful interventions, with interpersonal learning being related to a great extent on relational feedback. However, the relationship with the sociotherapist was emphasized as a source of emotional development, support, and feedback. It is related to the notion of alliance-building strategies, which have been shown to be important predictors of therapeutic outcome, especially when the engagement is perceived of by adolescents as being collaborative (Creed and Kendall 2005).

The second theme was designated 'intervention in crisis', with a crisis here being understood as being in an unresolvable dangerous situation - like complicated grief, overdosing on substances, or being a victim of sexual abuse or violent behavior by peers or family members (e.g., O'Halloran and Copeland 2000). When this factor is activated by the sociotherapists, they typically concentrate on immediate actions, often very dramatic and even at times perhaps overstepping the boundaries of neutrality. There is often a justified belief that when a teenager 
discloses to an adult, it is a unique occasion to help (see, for example, Crisma et al. 2004), so it may be assumed that that is the reason why sociotherapists often intervene in such way. Intervening in a crisis as a helping factor commonly stands out in the school setting and was narrated as being either progressive or regressive, but not stable in nature.

The process of helping adolescents seems to encompass not only verbal challenges during group or individual meetings, but also through social work, legal advice, working with families, or even a kind of foster-parenting, often in under-resourced situations (see also similar problems in Clarke and Quin 2007). As the findings here depict, some of the activities undertaken by sociotherapists might even be so absorbing that they disturb their work-life balance. As reported in another qualitative study on psychotherapists (Råbu et al. 2016), the impact of being a witness to suffering or destructiveness has been reported as a burden and might result in therapists becoming overwhelmed by responsibility and feelings of inadequacy, isolation, and despair.

The urge to intervene regardless of the personal cost can be understood as an effect of sociotherapists' decisions determined by their personal psychological operations, such as interdependence or denial of their own helplessness in favor of a sense of mission; but it can also certainly direct our attention toward (1) the social pressures (from the local community or institutions, especially schools) to which sociotherapists are subjected; and (2) the scale of the problems that affect young people needing to attend sociotherapy groups, including contrary common perspectives that they are 'only' adolescents at risk and a group process could suffice to help them. When designing interventions in sociotherapeutic groups (e.g., choosing to orient them as being more preventive or more therapeutic), it is perhaps worth taking into account the issue of interventions in crisis as being connected both to being in serious trouble and to developmental disturbances.

Furthermore, a controversial issue to contemplate is whether a school setting is in fact a proper setting for sociotherapy groups. The results of our research suggest that sociotherapists working in schools often needed to activate helping factors classified as interventions in crisis. This may indicate that the school is not the best place to conduct sociotherapy as a processbased group intervention. In our study, regressive outcomes were discovered both in the context of the school setting and in intervention in crisis work. In contrast, in the non-school (facility) setting, sociotherapists' narratives were told more as stable stories (without indication of a change either way), which may show that they were aware that improvements in mental functioning cannot be achieved immediately and that the effects of actions can only be seen after a long period of time.

In Poland, postgraduate training for sociotherapists is aimed at developing competencies and knowledge mainly in the field of group work (as evident in course programs such as the Polish Society of Sociotherapists and Trainers or the Polish Psychological Association). In the light of our findings, it seems evident that delivering group help in a school setting should include the aspect of intervention in crisis and perhaps family counselling (and/or social work with families), and that the support of the institution is needed in such circumstances. Sociotherapy providers should have appropriate specialist training and procedures to implement the necessary interventions, as these could go beyond the scope of the group-work aspect of the sociotherapy program.

\section{Limitations and Future Directions}

This study shares common flaws and strengths with other qualitative studies. The small and purposive sample, consensual theme development, and generally the exploratory design, to 
name only a few, have their obvious constraints. At the same time, sociotherapy as an object of scientific reflection is still in its infancy, so descriptive and problem-generating research is desirable. Moreover, we have made every effort to ensure that methodological decisions are transparent, and to integrate results in the context of the theoretical background of requirements from sociotherapy as a professional psychological and pedagogical field of helping.

Still, important questions about the two main themes distinguished in our study are worth highlighting. First, it should be highlighted that asking more directly about helping factors (a declaration-based study design) might result in different findings. Second, we remain with the question, 'to what extent do the two themes really coexist in sociotherapy as distinct categories of helping factors'? Or are they two ends of the same spectrum, meaning that it is impossible for a specific sociotherapist in a determined context (within the group) to both develop adolescents' competencies at a slow pace and to deliver help in an immediate way? The data show the co-occurrence of intervention in crisis with school settings, which seems to suggest the role of contextual factors. External circumstances may favor or inhibit certain aid factors, thus better recognition of contextual factors is needed in future studies. The method of choosing the most meaningful citation and then labelling it in every narrative in order to find uniqueness is perhaps not the right method to answer the question about the coexistence of the two main types of helping in the sociotherapeutic process. Further studies should be more focused on the specificity of sociotherapy settings (involving external circumstances as they do). We believe that discussion is still needed on how to match the effects of sociotherapy with participants' needs, and for which psychological problems sociotherapy is justified as a form of psychological and pedagogical help.

Although we cannot generalize our findings in any broad sense, we are certainly able to note an enrichment in such areas as: (1) general problems in designing group work help for youths; (2) problems that sociotherapy faces as a novice discipline in Poland in terms of evidence-based practice; and (3) specific problems with delivering psychological and pedagogical help in schools. These three areas at least are potential avenues for future qualitative and quantitative research projects.

Open Access This article is licensed under a Creative Commons Attribution 4.0 International License, which permits use, sharing, adaptation, distribution and reproduction in any medium or format, as long as you give appropriate credit to the original author(s) and the source, provide a link to the Creative Commons licence, and indicate if changes were made. The images or other third party material in this article are included in the article's Creative Commons licence, unless indicated otherwise in a credit line to the material. If material is not included in the article's Creative Commons licence and your intended use is not permitted by statutory regulation or exceeds the permitted use, you will need to obtain permission directly from the copyright holder. To view a copy of this licence, visit http://creativecommons.org/licenses/by/4.0/.

\section{References}

Ayres, L., Kavanagh, K., \& Knafl, K. (2003). Within-case and across-case approaches to qualitative data analysis. Qualitative Health Research, 1, 3871-3883.

APA, American Psychological Association (2017). Ethical Principles of Psychologists and Code of Conduct. Retreived from: https:/www.apa.org/ethics/code/ethics-code-2017.pdf (23.06.2019).

Braun, V., \& Clarke, V. (2006). Using thematic analysis in psychology. Qualitative Research in Psychology, $3(2), 77-101$.

Bruner, J. (1986). Actual minds, possible worlds. Cambridge, MA: Harvard University Press.

Cicchetti, D., \& Rogosch, F. A. (2002). A developmental psychopathology perspective on adolescence. Journal of Consulting and Clinical Psychology, 70(1), 6-20. 
Clandinin, D. J. (1985). Personal practical knowledge: A study of teachers' classroom images. Curriculum Inquiry, 15(4), 361-385.

Clarke, J., \& Quin, S. (2007). Professional carers' experiences of providing a pediatric palliative care service in Ireland. Qualitative Health Research, 17(9), 1219-1231.

Creed, T. A., \& Kendall, P. C. (2005). Therapist alliance-building behavior within a cognitive-behavioral treatment for anxiety in youth. Journal of Consulting and Clinical Psychology, 73(3), 498-505.

Crisma, M., Bascelli, E., Paci, D., \& Romito, P. (2004). Adolescents who experienced sexual abuse: Fears, needs and impediments to disclosure. Child Abuse \& Neglect, 28(10), 1035-1048.

Crockett, L. J., \& Petersen, A. C. (1993). Adolescent development: Health risks and opportunities for health promotion. In S. G. Millstein, A. C. Petersen, \& O. Nightingale (Eds.), Promoting the health of adolescents: New directions for the twenty-first century (pp. 13-37). New York: Oxford University Press.

Das, J. K., Salam, R. A., Lassi, Z. S., Khan, M. N., Mahmood, W., Patel, V., \& Bhutta, Z. A. (2016). Interventions for adolescent mental health: An overview of systematic reviews. Journal of Adolescent Health, 59(4), S49-S60.

Dahl, R. E., Allen, N. B., Wilbrecht, L., \& Suliman, A. B. (2018). Importance of investing in adolescence from a development al science perspective. Nature, 554(7693), 441-450.

Dierick, P., \& Lietaer, G. (2008). Client perception of therapeutic factors in group psychotherapy and growth groups: An empirically-based hierarchical model. International Journal of Group Psychotherapy, 58(2), 203-230.

Dryfoos, J. G. (1990). Adolescents at risk. London: Oxford University Press.

Gergen, K. J., \& Gergen, M. M. (1997). Narratives of the self. In L. Hinchman \& S. Hinchman (Eds.), Memory, identity, community: The idea of narrative in the human sciences (pp. 161-184). Albany: State University of New York.

Gonzalez, A., \& MacMillan, H. (2008). Preventing child maltreatment: An evidence-based update. Journal of Postgraduate Medicine, 54(4), 280-286.

Goddard, J. T., \& Foster, R. Y. (2001). The experiences of neophyte teachers: A critical constructivist assessment. Teaching and Teacher Education, 17(3), 349-365.

Grudziewska, E. (Ed.). (2015). Socjoterapia w pracy z dziećmi i młodzieża [Sociotherapy with children and adolescents]. Warszawa: Difin.

Gullotta, T. P. (2015). Understanding primary prevention. In T. P. Gullotta, R. W. Plant, \& M. A. Evans (Eds.), Handbook of adolescent behavioral problems: Evidence-based approaches to prevention and treatment (pp. 3-11). New York: Springer Science+Business Media Haynos.

Hiles, D., \& Cermák, I. (2008). Narrative psychology. In C. Willig \& W. Stainton-Rogers (Eds.), The SAGE handbook of qualitative research in psychology (pp. 147-164). London: SAGE Publications Ltd. https://oi. org/10.4135/9781848607927.

Holmbeck, G. N., Colder, C., Shapera, W., Westhoven, V., Kenealy, L., \& Updegrove, A. (2000). Working with adolescents. Guides from developmental psychology. In P. C. Kendall (Ed.), Child and adolescent therapy: Cognitive-behavioral procedures (2nd ed., pp. 334-385). New York: Guilford Press.

Hsieh, H.-F., \& Shannon, S. (2005). Three approaches to qualitative content analysis. Qualitative Health Research, 15, 1277-1288.

Jankowiak, B., \& Soroko, E. (2013). Socjoterapia jako forma pomocy psychologiczno-pedagogicznej. In B. Jankowiak (Ed.), Socjoterapia jako forma pomocy psychologiczno-pedagogicznej. Teoria i praktyka (pp. 33-58). Wydawnictwo Naukowe UAM: Poznań.

Jankowiak, B. (2017). Zachowania ryzykowne współczesnej młodzieży Studium teoretyczno-empiryczne. Poznań: Wydawnictwo Naukowe UAM.

Jankowiak, B., \& Soroko, E. (2020). Socjoterapia dzieci i młodzieży [Sociotherapy of children and adolescents]. In I. Grzegorzewska, L. Cierpiałkowska, \& A. Borkowska (Eds.), Psychologia kliniczna dzieci i młodzieży. Podręcznik akademicki (pp. 889-912). Warszawa: Wydawnictwo Naukowe PWN.

Kazak, A. E., Hoagwood, K., Weisz, J. R., Hood, K., Kratochwill, T. R., Vargas, L. A., \& Banez, G. A. (2010). A meta-systems approach to evidence-based practice for children and adolescents. American Psychologist, 65(2), 85-97. https://doi.org/10.1037/a0017784.

Kieling, C., Baker-Henningham, H., Belfer, M., Conti, G., Ertem, I., Omigbodun, O., Rohde, L. A., Srinath, S., Uluker, N., \& Rahman, A. (2011). Child and adolescent mental health worldwide: Evidence for action. The Lancet, 378(9801), 1515-1525.

Kivlighan, D. M., Jr., \& Tarrant, J. M. (2001). Does group climate mediate the group leadership-group member outcome relationship? A test of Yalom's hypotheses about leadership priorities. Group Dynamics: Theory, Research, and Practice, 5(3), 220.

Labov, W. (2009). Narratives of personal experience. In P. Hogan (Ed.), Cambridge encyclopedia of the language sciences (pp. 546-548). Cambridge: Cambridge University Press. 
Mayring, P. (2000). Qualitative content analysis. Forum: Qualitative Social Research On-line Journal, 1(2). Available: http://qualitative-research.net/fqs/fqs-e/2-00inhalt-e.tm [15.12.2003].

Morse, J. M. (2008). Confusing categories and themes. Qualitative Health Research, 18, 727-728.

Nowell, L. S., Norris, J. M., White, D. E., \& Moules, N. J. (2017). Thematic analysis: Striving to meet the trustworthiness criteria. International Journal of Qualitative Methods, 16(1), 1609406917733847.

O'Halloran, M. S., \& Copeland, E. P. (2000). Crisis intervention with early adolescents who have suffered a significant loss. In A. R. Roberts (Ed.), Crisis intervention handbook: Assessment, treatment, and research (pp. 101-130). New York: Oxford University Press.

Patton, M. Q. (2002). Qualitative research and evaluation methods. London: Sage Publications.

Råbu, M., Moltu, C., Binder, P. E., \& McLeod, J. (2016). How does practicing psychotherapy affect the personal life of the therapist? A qualitative inquiry of senior therapists' experiences. Psychotherapy Research, 26(6), 737-749.

Saldana, J. (2010). The coding manual for qualitative researchers. London: SAGE Publications Ltd.

Sales, J. M., \& Irwin, C. E., Jr. (2013). A biopsychosocial perspective of adolescent health and disease. In W. T. O’Donohue, L. T. Benuto, \& L. Woodward Tolle (Eds.), Handbook of adolescent Health Psychology (pp. 13-30). New York: Springer Science + Business Media.

Savin-Baden, M., \& Howell-Major, C. (2013). Qualitative research: The essential guide to theory and practice. Qualitative Research: The Essential Guide to Theory and Practice. Routledge.

Sawicka, K. (1999). Socjoterapia - Proces i metoda [Sociotherapy - process and method]. In K. Sawicka (Ed.), Socjoterapia [Sociotherapy] (pp. 9-28). Warszawa: CMPPP.

Sexton, T. L., Fisher, A. R., Graham, C., \& Elnahraw, N. A. (2015). Evidence-based practice in the prevention and treatment of adolescent behavior problems. In T. P. Gullotta, R. W. Plant, \& M. A. Evans (Eds.), Handbook of adolescent behavioral problems: Evidence-based approaches to prevention and treatment (pp. 85-106). New York: Springer Science+Business Media.

Sexton, T. L., Gilman, L., \& Johnson-Erickson, C. (2005). Evidence-based practices. In T. P. Gullotta \& G. R. Adams (Eds.), Handbook of adolescent behavior problems (pp. 101-128). New York: Springer.

Shechtman, Z., Bar-El, O., \& Hadar, E. (1997). Therapeutic factors and psychoeducational groups for adolescents: A comparison. The Journal for Specialists in Group Work, 22(3), 203-213.

Shechtman, Z., \& Gluk, O. (2005). An investigation of therapeutic factors in children's groups. Group Dynamics: Theory, Research, and Practice, 9(2), 127-134.

Silverman, W. K., \& Hinshaw, S. P. (2008). The second special issue on evidence-based psychosocial treatments for children and adolescents: A 10-year update. Journal of Clinical Child \& Adolescent Psychology, 37(1), $1-7$.

Soroko, E. (2009). Wywoływanie autonarracji w badaniach psychologicznych. Ocena (auto) narracyjności wypowiedzi [Self-narrative eliciting in psychological research. Self-narrativity assessment]. Poznań: Wydawnictwo Naukowe UAM.

Strzemieczny, J. (1988). Zajęcia socjoterapeutyczne dla dzieci w wieku szkolnym. W J. Strzemieczny (red.), Zajęcia socjoterapeutyczne [Sociotherapeutic classes] (pp. 5-51). Warszawa: Polskie Towarzystwo Psychologiczne. Ośrodek Rozwoju Umiejętności Wychowawczych.

Szczepanik, R., \& Jaros, A. (2016). Techniki socjoterapeutyczne $w$ pracy $z$ dzieckiem agresywnym. [Sociotherapeutic techniques in working with an aggressive child]. Łódź: Wydawnictwo Uniwersytetu Łódzkiego.

Takanishi, R. (1993). Changing views of adolescence in contemporary society. Teachers College Record, 94(3), $459-465$.

Vaismoradi, M., Turunen, H., \& Bondas, T. (2013). Content analysis and thematic analysis: Implications for conducting a qualitative descriptive study. Nursing \& Health Sciences, 15(3), 398-405.

Weisz, J. R. (1997). Effects of interventions for child and adolescent psychological dysfunction: Relevance of context, developmental factors, and individual differences. In S. S. Luthar, J. Burack, D. Cicchetti, \& J. R. Weisz (Eds.), Developmental psychopathology: Perspectives on adjustment, risk, and disorder (pp. 3-22). New York: Cambridge University Press.

Wilk, M. (2014). Diagnoza w socjoterapii [Sociotherapeutic assessment]. Gdańsk: Gdańskie Wydawnictwo Psychologiczne.

Yalom, I. D., \& Leszcz, M. (2005). The theory and practice of group psychotherapy (5th ed.). New York: Basic Books.

Publisher's Note Springer Nature remains neutral with regard to jurisdictional claims in published maps and institutional affiliations. 